\title{
Temporal macular thinning: a salient sign of Alport syndrome
}

\author{
Sharan Silvarajoo, Yong Zheng Wai, Jamalia Rahmat
}

Department of Ophthalmology, Kuala Lumpur General Hospital, Kuala Lumpur, Malaysia

\section{Abstract}

Alport syndrome is a hereditary, multisystemic disorder that causes abnormalities of the ear, kidney, and eye. A teenager who was suffering from end-stage renal failure and hearing problems was referred to us suspected of Alport syndrome. He did not have any ocular complaints and wore glasses for myopic astigmatism. His best-corrected visual acuity was $6 / 7.5$ bilaterally. Anterior segment examination was unremarkable. Posterior segment examination showed perimacular dot-andfleck retinopathy with bull's eye maculopathy. Optical coherence tomography revealed temporal macular thinning. The findings were in keeping with the diagnosis of X-linked Alport syndrome. Ocular findings can help diagnose Alport syndrome. Early detection and treatment can help delay the progression of kidney failure.

Keywords: Alport syndrome, dot-and-fleck perimacular retinopathy, temporal macular thinning

\section{Abstrak}

Sindrom Alport adalah penyakit keturunan, melibatkan multisistem yang menyebabkan masalah pada telinga, ginjal, dan mata. Seorang remaja yang mengalami masalah ginjal di peringkat kritikal dan masalah pendengaran dirujuk kepada kami dan disyaki menghidap sindrom Alport. Dia tidak mempunyai keluhan okular dan memakai kacamata untuk astigmatisme rabun. Penglihatannya ialah 6 / 7.5 pada kedua-dua mata. Pemeriksaan segmen anterior tidak menpunyai

Correspondence: YDr. Sharan Silvarajoo, MD, Hospital Kuala Lumpur, 23, Jalan Pahang, 50586 Kuala Lumpur, Malaysia.

E-mail:dr.sharan86@gmail.com 
sebarang masalah tetapi pemeriksaan segmen posterior menunjukkan retinopati titik-dan-flek perimakular dengan makulopati mata lembu. Tomografi koheren optik menunjukkan penipisan makula di bahagian temporal. Penemuan ini sesuai dengan diagnosis sindrom Alport yang berkaitan dengan pautan X. Penemuan okular dapat membantu mendiagnosis sindrom Alport. Pengesanan dan rawatan awal dapat membantu melambatkan kegagalan buah pinggang.

Kata kunci: penipisan makula temporal, retinopati titik-dan-flek perimakular, sindrom Alport

\section{Introduction}

Alport syndrome (AS) is a rare genetic disorder caused by a mutation in collagen IV genes $C O L 4 A 3, C O L 4 A 4$, and $C O L 4 A 5$, which are primarily located in the basement membrane of the kidneys, eyes, and cochlea. AS can be transmitted as an X-linked, autosomal recessive, or autosomal dominant pattern. Among patients with AS, $85 \%$ are X-linked AS (XLAS) with a prevalence of 1 in 50,000 individuals and male preponderance. ${ }^{1,2}$

\section{Case presentation}

A 14-year-old teenager suspected of AS was referred to us for ocular assessment by a nephrologist. The patient was under the specialist's follow-up for haematuria and had been diagnosed with end-stage renal failure. An otolaryngologist was also following the case for bilateral sensorineural hearing impairment since the age of 5; the patient was doing well with hearing aids. His paternal uncle had suffered kidney failure in his early 40 s with an unknown cause. The patient had been offered genetic testing, but due to financial constraints, the option was not taken.

On ocular examination, best-corrected visual acuity was 6/7.5 (-5.50/-1.25 x $5)$ in the right eye and 6/7.5 (-5.25/-2.00 x 170) in the left eye. Anterior segment examination was unremarkable. There was perimacular dot-and-fleck retinopathy with bull's eye maculopathy on fundus examination of the right and left eye (Fig. 1A, B); Figure 1C shows a magnified view of the macula. Optical coherence tomography (OCT) showed temporal macular thinning of the right and left eye (Fig. 2). This supported the diagnosis of AS. 


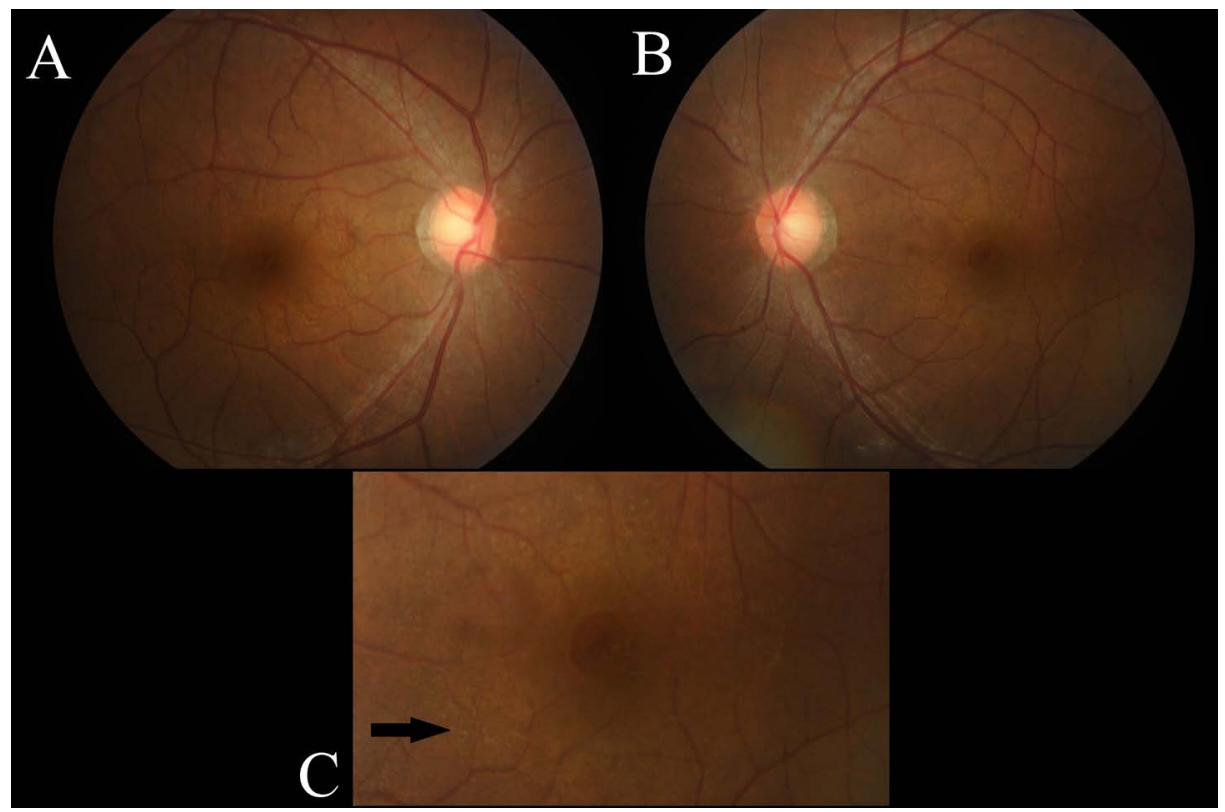

Fig. 1. Perimacular dot-and-fleck retinopathy in the right eye $(A)$ and the left eye $(B)$. $(C)$ Magnified fundus photo shows perimacular yellowish dot-and-flecks retinopathy (arrow) with bull's eye maculopathy.
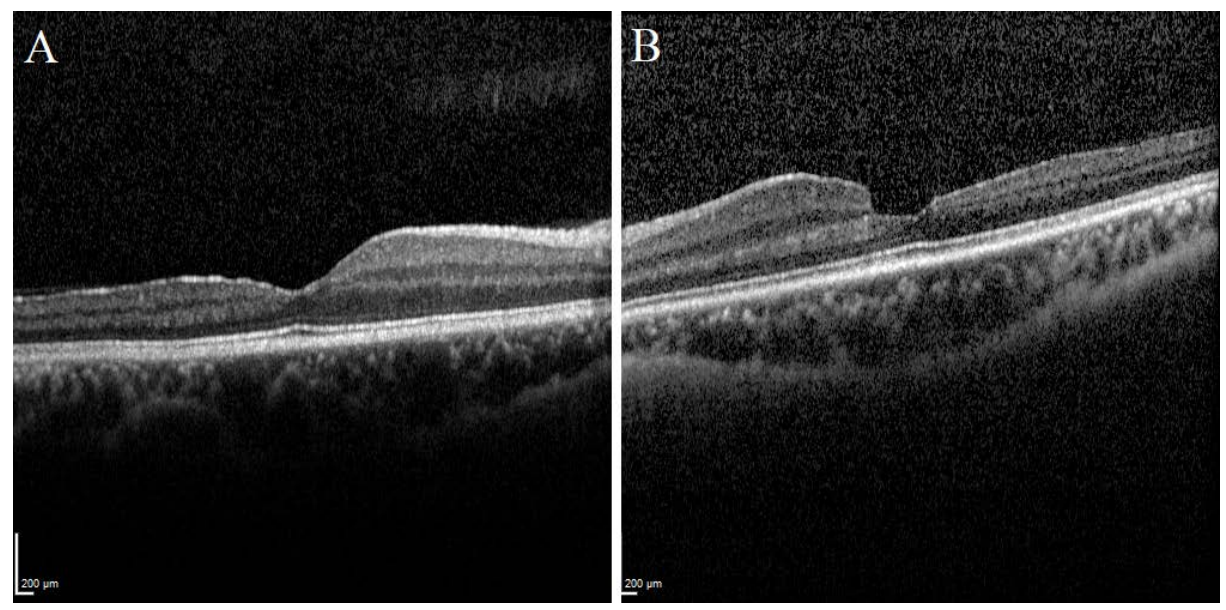

Fig. 2. Temporal macular thinning on optical coherence tomography in the right eye $(A)$ and the left eye $(B)$. 


\section{Discussion}

AS is a multisystemic, inherited disease characterized by hearing loss, haematuria, progressive renal failure, and ocular abnormalities. Ocular abnormalities result from mutation of collagen type IV, which is the most abundant protein found in the basement membranes of the cornea (Descemet's and Bowman's membranes), lens capsule, choroid (Bruch's membrane), and retina (inner limiting membrane). ${ }^{1,3}$

Ocular manifestations of AS include posterior polymorphous corneal dystrophy, recurrent corneal erosion, anterior and posterior lenticonus and cataracts, central and perimacular dot-and-fleck retinopathy, temporal macular thinning, dull foveal reflex (lozenge), bull's eye or vitelliform maculopathy, and lamellar or giant macular hole. ${ }^{3,4}$

Central or perimacular retinopathy is seen in $60 \%$ of men and $15 \%$ of women with XLAS. ${ }^{5}$ The retinopathy manifests as scattered whitish-yellowish dots with variable density. These are amorphous deposits of acellular debris, lipids, and protein located between the pigment epithelium and Bruch's membrane. The retinopathies, like the other clinical features in AS, may depend on the direct effect of the underlying COL4A5 mutations on the retinal basement membranes. ${ }^{2,4}$ This finding becomes more prominent with time; however, visual acuity is substantially normal and no treatment is required.

Temporal macular thinning on OCT has been highlighted as the commonest ocular finding in X-linked and recessive AS, with an incidence ranging from 75-90\% in males and $55-75 \%$ in females. ${ }^{6}$ Kandon et al. reported a cohort of 32 patients with temporal macular thinning, which occurs frequently in male patients with XLAS; this specific sign helps not only for diagnosis but also for prognostication of XLAS. ${ }^{5}$ Savige and colleagues had similar findings in their observation of 10 patients with Alport syndrome. ${ }^{1}$

Ocular manifestation is exceptionally helpful in predicting the inheritance pattern of AS in a diagnostic dilemma when genetic testing is not readily available. As in our case, confirmatory genetic testing was turned down due to unaffordable cost. With the availability of noninvasive OCT, temporal macular thinning can be easily detected, contributing to the diagnosis of AS and its inheritance. In a condition where genetic testing and renal biopsy are not feasible, macular OCT is the cheapest, painless, and most readily available investigation that can aid of diagnosis of AS. Macular OCT showing temporal thinning can provide a hint to clinicians to investigate further for XLAS, as other ocular signs can be subtle, and clinicians might miss the diagnosis.

Chen et al. reported that temporal macular thinning is associated with younger age of onset of renal failure. ${ }^{7}$ Early onset of renal failure is usually progressive, leading to end-stage renal failure requiring a renal transplant. Ophthalmological findings are thus crucial in the early diagnosis of XLAS. Although it has no implication on vision, early detection improves prognosis. Timely treatment with 
angiotensin-converting enzyme inhibitor helps in slowing the deterioration and inevitable progression to end-stage renal failure, which could relatively improve life expectancy.

\section{Conclusion}

Temporal macular thinning together with dot-and fleck-retinopathy are salient signs that can help in the diagnosis of XLAS. These signs can also predict the prognostic value in determining the nature of renal failure which commonly progressive and if treated early can delay the onset of end-stage renal failure.

\section{Declarations}

\section{Consent for publication}

Informed consent for the publication of the patient's images and clinical data was obtained from the patient's parents.

\section{Funding}

None to declare.

\section{Competing interests}

None to declare. Conflict of interest statements were attached with the manuscript submission.

\section{Acknowledgements}

The authors would like to thank the Director General of Health Malaysia for permission to publish this paper.

\section{References}

1. Savige J, Sheth S, Leys A, et al. Ocular features in Alport syndrome: pathogenesis and clinical significance. Clin J Am Soc Nephrol. 2015;10:703-9. https://doi.org/10.2215/CJN.10581014

2. Colville DJ, Savige J. Alport syndrome. A review of the ocular manifestations. Ophthalmic Genet. 1997;18:161-73. https://doi.org/10.3109/13816819709041431

3. Jais JP, Knebelmann B, Giatras I, et al. X-linked Alport syndrome: Natural history in 195 families and genotype- phenotype correlations in males. J Am Soc Nephrol. 2000;11:649-657. PMID: 10752524.

4. Tan R, Colville D, Wang YY, Rigby L, Savige J. Alport retinopathy results from "severe" COL4A5 mutations and predicts early renal failure. Clin J Am Soc Nephrol. 2010;5:34-38. https://doi. org/10.2215/CJN.01030209 
5. Ahmed F, Kamae KK, Jones DJ, et al. Temporal Macular Thinning Associated With X-Linked Alport Syndrome. JAMA Ophthalmol. 2013;131(6):777-782. https://doi.org/10.1001/jamaophthal$\underline{\text { mol.2013.14526 }}$

6. Gupta V, Jamil M, Luthra S, et al. Alport syndrome with bilateral simultaneous anterior and posterior lenticonus with severe temporal macular thinning. BMJ Case Rep. 2019;12:e229554. https:// doi.org/10.1136/bcr-2019-229554

7. Chen $\mathrm{Y}$, Colville $\mathrm{D}$, lerino $\mathrm{F}$, et al. Temporal retinal thinning and the diagnosis of Alport syndrome and Thin basement membrane nephropathy. Ophthalmic Genet. 2018;39:208-14. https://doi.org/ $\underline{10.1080 / 13816810.2017 .1401088}$ 